Journal of Civic Education (ISSN:2622-237X)

Volume 2 Nomor 22019

\title{
KETERAMPILAN DASAR MENGAJAR GURU PADA PEMBELAJARAN PENDIDIKAN KEWARGANEGARAAN (PKn) DI SMPN 1 IV KOTO KABUPATEN AGAM
}

Tysa Sufia Rahmi

STKIP Ahlussunnah Bukittinggi

tysa.sufia@gmail.com

Abstract

This event will be based on research because there are still teachers who have yet to implement skills Pkn asked intact. ask skills is one of the basic skills that must be taught by each teacher dimiliPKn, because in every teaching and learning to ask students is the thing that can not be left by the teacher. with the ability to ask a teacher will be able to dig up the entire ability of students to think and could invite students to develop critical thinking and ability. Implementation of the teaching skills of teachers PKn SMP 1 IV Koto is still not fit properly, because not all of the indicators of basic skills teaching carried out by teachers as a whole on the implementation of the learning in the classroom. Factors that influence the teaching of basic skills teachers is the lack of awareness of teachers in improving teaching skills, lack of training obtained by teachers PKn SMP 1 IV Koto about teaching basic skills teacher.

Key Words : skill, asking, teacher

\section{PENDAHULUAN}

Dalam rangka mencapai tujuan pendidikan nasional bukanlah persoalan yang mudah, dalam proses pendidikan diperlukan penanganan yang betul-betul mampu menguasai masalah-masalah pendidikan nasional yang dicita-citakan dapat tercapai. Untuk dapat mewujudkan output pendidikan yang diharapkan tidak lepas dari faktorfaktor pendukung dari pendidikan itu sendiri disamping faktor lainya, salah satu faktor yang sangat mempengaruhi output pendidikan adalah keterampilan seorang guru PKn dalam melaksanakan pembelajaran di kelas, karena keterampilan mengajar guru PKn dalam pembelajaran menentukan kualitas penggajaran yang dilaksanakanya. Salah satu keterampilan mengajar yang harus dimiliki oleh seorang guru adalah keterampilan bertanya.

Menurut Wingkel dalam Oemar Hamalik (2003 : 30), guru yang terampil akan mampu menerapkan keterampilan-keterampilan sebagai guru dalam kegiatan mengajar, karena keterampilan dalam mengajar harus dikuasai oleh guru. Ada beberapa jenis keterampilan guru dalam mengajar yaitu: a. Keterampilan bertanya b. Keterampilan memberi penguatan c. Keterampilan mengadakan variasi d. 
Keterampilan menjelaskan e. Keterampilan membuka dan menutup pelajaran f. Keterampilan membimbing diskusi kelompok kecil g. Keterampilan mengelola kelas h. Keterampilan mengajar kelompok kecil dan perorangan.

Salah satu keterampilan dasar yang sangat perlu dikuasai oleh guru PPKn adalah keterampilan bertanya. Bertanya merupakan ucapan verbal yang meminta respon dari seseorang yang dikenai (Hasibuan dan Moedjiono 1995:62). Brown (dalam Hasibuan 1995:19) mendefinisikan bahwa bertanya adalah setiap pertanyaan yang mengkaji atau menciptakan ilmu pada diri siswa. Jadi, pertanyaan yang dilontarkan oleh guru merupakan ucapan verbal yang meminta respon dari siswanya dengan tujuan mengkaji atau menciptakan ilmu pada diri siswa. Respon siswa terhadap pertanyaan guru merupakan umpan balik yang dapat meningkatkan keefektifan pembelajaran. Sehingga, pertanyaan guru merupakan stimulus efektif pendorong kemampuan berpikir siswa. Oleh sebab itu keterampilan bertanya harus dilaksanakan oleh guru PKn dalam kelas, karena keterampilan bertanya guru tidak hanya sekadar wajib dikuasai oleh guru, namun juga wajib diterapkan pada pelaksanaan pembelajaran di kelas agar melalui pertanyaan yang diajukan oleh guru dapat memberikan stimulus kepada siswa, sehingga akan mampu mendorong kemampuan siswa dalam berfikir kritis.

Fakta dilapangan menunjukan bahwa di SMPN 1 IV Koto Kabupaten Agam guru PKn ditemui masih ada yang belum melaksanakan keterampilan bertanya dengan baik, hal ini terlihat dari pertanyaan yang dilontarkan oleh guru dalam pelaksanaan pembelajaran yang belum dapat memberi stimulus kepada siswa, dan belum sepenuhnya bisa menggali seluruh potensi yang dimiliki oleh siswa sehingga proses pembelajaran tidak berjalan dengan efektif. Hal ini sejalan dengan pendapat Sagala (2009:23) mengatakan kompetensi adalah perpaduan dari penguasaan pengetahuan, keterampilan, nilai dan sikap yang direfleksikan dalam kebiasaan berpikir dan bertindak dalam melaksanakan tugas dan pekerjaanya. Ia menambahkan bahwa bahwa kompetensi merupakan gabungan dari kemampuan, pengetahuan, kecakapan, sikap, sifat, pemahaman, apresiasi dan harapan yang mendasari karakteristik seseorang untuk berunjuk kerja dalam melaksanakan tugas atau pekerjaan guna mencapai standar kualitas dalam pekerjaan nyata.

\section{LANDASAN TEORI}

Bertanya merupakan ucapan verbal yang meminta respon dari seseorang yang dikenai (Hasibuan dan Moedjiono 1995:62). Brown (dalam Hasibuan 1995:19) mendefinisikan bahwa bertanya adalah setiap pertanyaan yang mengkaji atau menciptakan ilmu pada diri siswa. Jadi, pertanyaan yang dilontarkan oleh guru merupakan ucapan verbal yang meminta respon dari siswanya dengan tujuan mengkaji atau menciptakan ilmu pada diri siswa. Respon siswa terhadap pertanyaan guru merupakan umpan balik yang dapat meningkatkan keefektifan pembelajaran. Sehingga, pertanyaan guru merupakan stimulus efektif pendorong kemampuan berpikir siswa. 
Secara umum, seseorang bertanya untuk memperoleh informasi. Dalam sebuah pembelajaran yang produktif, kegiatan bertanya bertujuan untuk (1) menggali informasi, baik administrasi maupun akademis, (2) mengecek pemahaman siswa, (3) membangkitkan respon pada siswa, (4) mengetahui sejauh mana keingintahuan siswa, (5) mengetahui hal-hal yang sudah diketahui siswa, (6) memfokuskan perhatian siswa pada sesuatu yang dikehendaki guru, (7) untuk membangkitkan lebih banyak lagi pertanyaan dari siswa, dan (8) untuk menyegarkan kembali pengetahuan siswa (Sagala 2009:88-89).

Marno (2008:131-132) dan Usman (1990:66) mengemukakan bahwa pertanyaaan yang tersusun baik dengan teknik pelontaran yang tepat akan memberikan dampak positif terhadap siswa, yaitu (1) meningkatkan partisipasi siswa dalam kegiatan belajar mengajar, (2) membangkitkan minat dan rasa ingin tahu siswa terhadap suatu masalah yang sedang dihadapi atau dibicarakan, (3) mengembangkan pola berpikir dan cara belajar aktif dari siswa, (4) menuntun proses berpikir siswa, dan (5) memusatkan perhatian siswa terhadap masalah yang sedang dibahas. Seorang guru penting untuk menguasai keterampilan bertanya. Bertanya dengan baik berarti mengajar dengan baik. Dengan bertanya berarti guru membimbing siswa dalam belajar. Pendistribusian pertanyaan secara benar dan tepat oleh guru akan membantu belajar siswa. Pertanyaan yang tersusun dengan baik adalah separuh jawaban dari pertanyaan itu sendiri. Pertanyaan guru yang tidak terjawab oleh siswa, boleh jadi karena kurangnya penguasaan guru dalam menyusun pertanyaan.

Keterampilan dasar mengajar bertanya dibedakan atas keterampilan dasar mengajar bertanya tingkat dasar dan keterampilan dasar mengajar bertanya tingkat lanjut (Hasibuan 1995:21). Keterampilan dasar bertanya tingkat dasar berkaitan dengan penerapan dalam mengajukan segala jenis pertanyaan. Sehingga, komponen-komponen dalam keterampilan dasar bertanya tingkat dasar merupakan aspek teknik dalam bertanya. Keterampilan dasar bertanya tingkat lanjut merupakan kelanjutan dari keterampilan dasar bertanya tingkat dasar yang berfungsi untuk mengembangkan kemampuan berpikir siswa, memperbesar partisipasi siswa, serta mendorong siswa untuk dapat mengambil inisiatif sendiri. Komponen-komponen keterampilan dasar bertanya tingkat lanjut merupakan aspek isi yang berkaitan dengan jenis-jenis pertanyaan.

Faktor-faktor yang harus diperhatikan dalam mengajukan pertanyaan menurut Marno (2008:141) antara lain adalah (1) kejelasan dan kaitan pertanyaan, (2) kecepatan dan selang waktu (pause), (3) arah dan distribusi penunjukan (penyebaran), (4) teknik penguatan, (5) teknik menuntun (prompting), (6) teknik menggali (probing question), (7) pemusatan (focussing), dan (8) pindah gilir. Beberapa komponen dalam keterampilan dasar bertanya tingkat dasar tersebut perlu diterapkan dalam mengajukan segala jenis pertanyaan.

Sejalan dengan pemikiran Hasibuan dan Moedjiono tersebut, Usman (1990:69) menjelaskan bahwa komponen-komponen keterampilan bertanya dasar adalah (1) 
penggunaan pertanyaan secara jelas dan singkat, (2) pemberian acuan, (3) pemindahan giliran, (4) penyebaran, (5) pemberian waktu berpikir, dan (6) pemberian tuntunan. Keterampilan dasar mengajar bertanya tingkat lanjut merupakan lanjutan dari keterampilan dasar mengajar bertanya tingkat dasar yang berfungsi untuk mengembangkan respon serta kualitas jawaban siswa setelah diperoleh jawaban sebelumnya. Sehingga dalam penerapannya, komponen-komponen bertanya tingkat dasar masih digunakan dalam keterampilan bertanya tingkat lanjut.

Berdasarkan beberapa pendapat tersebut, disimpulkan bahwa komponenkomponen keterampilan dasar bertanya tingkat lanjut berkaitan dengan jenis-jenis pertanyaan, yang meliputi (1) pengubahan tuntunan tingkat kognisi dalam menjawab pertanyaan, (2) pengaturan urutan pertanyaan, (3) penggunaan pertanyaan pelacak, dan (4) peningkatan terjadinya interaksi. Kemampuan berpikir siswa, partisipasi serta kreatifitas siswa dikembangkan dengan mengintegrasikan berbagai jenis pertanyaan dalam komponen keterampilan bertanya tingkat lanjut sebagai lanjutan dari keterampilan bertanya tingkat dasar.

\section{PEMBAHASAN}

\section{Pelaksanaan Keterampilan Dasar Mengajar Guru PKn Pada Pembelajaran Pendidikan Kewarganegaraan (PKn)}

Dari hasil temuan penelitian berkaitan pelaksanaan keterampilan bertanya guru PKn pada pembelajaran di kelas, bahwa guru PKn harus melaksanakan seluruh indikator-indikator dari keterampilan bertanya secara utuh dalam pembelajaran di kelas. Akan tetapi pada kenyataanya guru PKn SMPN 1 IV Koto masih belum melaksanakan kesemua indikator keterampilan bertanya dalam melaksanakan pembelajaran PKn. padahal seharusnya keterampilan bertanya guru haruslah mampu membangkitkan respon siswa dalam belajar, menfokuskan perhatian siswa dalam belajar, dan menyegarkan kembali pengetahuan siswa dengan mengaitkan dengan pembelajaran yang telah lampau.

Sesuai dengan pendapat Marno (2008:141) menjelaskanfaktor-faktor yang harus diperhatikan dalam mengajukan pertanyaan antara lain adalah (1) kejelasan dan kaitan pertanyaan, (2) kecepatan dan selang waktu (pause), (3) arah dan distribusi penunjukan (penyebaran), (4) teknik penguatan, (5) teknik menuntun (prompting), (6) teknik menggali (probing question), (7) pemusatan (focussing), dan (8) pindah gilir.

Dari hasil penelitian dan ditunjang dengan pendapat ahli di atas dapat ditegaskan bahwa pemahaman guru tentang keterampilan bertanya tidak hanya sebatas menggali informasi, mengecek pemahaman siswa, mengetahui hal-hal yang sudah diketahui oleh siswa. akan tetapi harus lah memperhatikan indikator yang lainnya, seperti membangkitkan respon siswa, menfokuskan perhatian siswa, membenagkitkan lebih banyak lagi pertanyaan dari siswa. dan agar guru bisa meperhatikan hal tersebut, maka dalam bertanya guru harus memahami lagi faktorfaktor yang dapat mempengaruhi keterampilan bertanya guru, seperti : guru harus memperhatikan kejelasan pertanyaan yang diberikan, kemudian teknik penguatan 
dalam memberi pertanyaan, teknik menunutun, menggali. Sehingga dengan demikian seluruh indikator dari keterampilan bertanya guru bisa diterapkan dengan baik.

Bukhari Alma (2010:31) menjelaskan hal yang harus diperhatikan guru dalam dalam memberikan pertanyaan adalah setelah guru mengajukan pertanyaan, murid diminta tenang sebentar, ini bertujuan untuk : a. memberikan kesempatan berfikir mencari jawaban b. Untuk memperoleh jawaban yang komplit c. Memahami pertanyaan/menganalisa pertanyaan d. Agar banyak murid yang menjawab.

Berdasarkan pendapat di atas maka dapat dikatakan bahwa pertanyaan yang diberikan guru haruslah memunculkan respon dan pertanyaan balikan dari siswa, maka hal-hal yang harus diperhatikan guru dalam bertanya adalah dengan memberikan kesempatan kepada siswa untuk mencari jawaban dari pertanyaan yang diberikan, selain itu juga nanti guru akan mendapat jawaban yang komplit dari siswa, dan juga siswa akan mampu menganalisa pertanyaan yang diberikan dan mampu menjawabnya dengan tepat.

Temuan penelitian juga menjelaskan bahwa pemahaman guru PKn SMPN 1 IV Kot Kabupaten Agam tentang keterampilan bertanya masih belum bisa untuk menfokuskan perhatian siswa, karena guru sudah melemparkan pertanyaan kepada siswa ketika siswa masih banyak yang belum siap dalam belajar. Padahal seharusnya guru terlebih dahulu harus menfokuskan perhatian siswa terlebih dahulu sebelum mengajukan pertanyaa. Hal ini bertujuan agar semua siswa bisa menganalisa pertanyaan yang diberikan oleh guru.

Sesuai dengan pendapat Bukhari Alma (2010:36) menjelaskan pertanyaan yang diajukan oleh guru dimaksudkan untuk menciptakan kondisi emosional, karena itu pertanyaan ini tidak berhubungan dengan bahan pelajaran. Contoh : jika tiba-tiba kelas ribut, mungkin guru dapat memberikan pertanyaan menggunakan kalimat apakah ada yang ingin ditanyakan?.

Dari hasil penelitian dan ditunjang dengan pendapat Bukhari Alma di atas maka dapat dikatakan bahwa sebelum mengajukan pertanyaan kepada siswa, hendaknya guru terlebih dahulu memperhatikan sikap siswa apakah siswa sudah fokus atau belum, jika belum hendaknya guru menfokuskan perhatian siswa terlebih dahulu dengan memberikan pertanyaan pancingan agar siswa memperhatikan apa yang ditanyakan guru. Menfokuskan siswa sebelum mengajukan pertanyaan akan lebih membantu siswa dalam menganalisa pertanyaan yang diberikan sehingga siswa bisa menjawab pertanyaan dengan komplit.

\section{Faktor-Faktor yang Mempengaruhi Keterampilan Dasar Mengajar Guru PKn pada Pembelajaran PKn di SMPN 1 IV Koto Kabupaten Agam.}

Dari temuan penelitian yang menjadi faktor yang mempengaruhi keterampilan bertanya guru adalah kurangnya kesadaran guru dalam meningkatkan keterampilan mengajarnya. Hal ini disebabkan bahwa guru tidak hanya tergantung dari pelatihanpelatihan yang diperolehnya dalam mengembangkan keteraampilannya. Akan tetapi 
harus ada kesadaran dari guru itu sendiri untuk mengembangkan keterampilan yang dimilikinya.

Sesuai dengan pendapat Murphy dalam Mulyasa (2009:8) menjelaskan bahwa keberhasilan pembaharuan sekolah sangat ditentukan oleh gurunya, karena guru adalah pemimpin pembelajaran, fasilitator, dan sekaligus merupakan pusat inisiatif pembelajaran. Karena itu, guru harus senantiasa mengembangkan diri secara mandiri serta tidak tergantung pada inisiatif sekolah dan supervisor.

Dari temuan penelitian tentang faktor-fator yang mempengaruhi keterampilan bertanya guru PKn SMPN 1 IV Koto Kabupaten Agam, menunjukan bahwa salah satu faktor yang mempengaruhi keterampilan bertanya guru adalah kurangnya pelatihan yang diperoleh oleh guru PKn SMPN 1 IV Koto Kabupeten Agam. padahal dengan dilakukan pelatihan bisa mengembangkan keterampilan mengajar guru dalam pelaksanaan pemebelajaran di kelas.

Dari temuan penelitian dan didukung dengan pendapat ahli ditegaskan bahwa keterampilan bertanya guru harus ditingkatkan melalaui pelatihan yang diberikan.

\section{KESIMPULAN}

1. Pelaksanaan keterampilan bertanya oleh guru PKn SMPN 1 IV Koto kabupaten Agam adalah bahwa guru belum melaksanakan keterampilan bertanya secara maksimal, belum lagi melaksanakan indikator keterampilan bertanya secara rutin pada setiap kali pertemuan. Indikator yang sudah dilaksanakan yaitu guru menggali informasi, mengecek pemahaman siswa, dan mengetahui sejauh mana keingintahuan siswa. sedangkan indikator yang masih belum terlihat yaitu membangkitkan respon dari siswa, mengetahui hal-hal yang sudah diketahui siswa, menfokuskan perhatian siswa, membangkitkan respon lebih banyak lagi dari siswa, dan menyegarkan kembali pengetahuan siswa.

2. Faktor-faktor yang mempengaruhi guru dalam melaksanakan keterampilan bertanya adalah kurangnya kesadaran guru dalam meningkatkan kemampuan dan kurangnya pelatihan yang didapat oleh guru.

\section{DAFTAR RUJUKAN}

Hamalik, Oemar. 2003. Pendidikan Guru Berdasarkan Pendekatan Kompetensi. Jakarta: Bumi Aksara.

Alma, Bukhari dkk, 2010. Guru Prefesional. Menguasai Metode Dan Terampil Mengajar. Bandung : Alfabeta.

Hasibuan, Moedjiono. 1995. Proses Belajar Mengajar. Bandung. Remaja Rosdakarya.

Marno, M. 2008. Strategi dan Metode Pengajaran. Jogjakarta : Ar-Ruzz Media. Mulyasa. 2009. Menjadi Guru Professional. Bandung: PT. Remaja Rosdakarya.

Sagala, Syaiful. 2009. Kemampuan Profesional Guru dan Tenaga Kependidikan.

Bandung: Alfabeta.

Usman, 1990. Guru Profesional. Jakarta : Gramedia. 